\title{
Spontaneous revegetation of a peatland in Manitoba after peat extraction: diversity of plant assemblages and restoration perspectives
}

\begin{tabular}{|c|c|}
\hline Journal: & Botany \\
\hline Manuscript ID & $c j b-2018-0109 . R 1$ \\
\hline Manuscript Type: & Article \\
\hline $\begin{array}{r}\text { Date Submitted by the } \\
\text { Author: }\end{array}$ & 25-Jul-2018 \\
\hline Complete List of Authors: & $\begin{array}{l}\text { Gagnon, Félix; Universite Laval, Ecole superieure d'amenagement du } \\
\text { territoire et de developpement regional and Centre d'etudes nordiques } \\
\text { Rochefort, Line; University Laval, } \\
\text { Lavoie, Claude; Universite Laval, Ecole superieure d'amenagement du } \\
\text { territoire et de developpement regional and Centre d'etudes nordiques }\end{array}$ \\
\hline Keyword: & $\begin{array}{l}\text { Eriophorum vaginatum, fen, peatland restoration, Scirpus cyperinus, } \\
\text { spontaneous revegetation }\end{array}$ \\
\hline $\begin{array}{r}\text { Is the invited manuscript for } \\
\text { consideration in a Special } \\
\text { Issue? : }\end{array}$ & Not applicable (regular submission) \\
\hline
\end{tabular}

\section{SCHOLARONE Manuscripts}




\title{
Spontaneous revegetation of a peatland in Manitoba after peat extraction: diversity of plant assemblages and restoration perspectives
}

\author{
Félix Gagnon, Line Rochefort and Claude Lavoie
}

F. Gagnon and C. Lavoie. École supérieure d'aménagement du territoire et de développement régional and Centre d'études nordiques, Université Laval, 2325, rue des Bibliothèques, Québec, QC G1A 0V6, Canada (e-mail: F.G. : fgagnon@zipcng.org; C.L.: claude.lavoie@esad.ulaval.ca).

L. Rochefort. Peatland Ecology Research Group and Centre d'études nordiques, Université Laval, 2425, rue de l'Agriculture, Québec, QC G1A 0V6, Canada (e-mail:

line.rochefort@fsaa.ulaval.ca).

Corresponding author: Claude Lavoie, École supérieure d'aménagement du territoire et de développement régional, Université Laval, 2325, rue des Bibliothèques, Québec, QC G1A 0V6, Canada. Tel.: 1-418-656-2131 ext. 5375; Fax: 1-418-656-2018. Email: claude.lavoie@esad.ulaval.ca. 
Abstract: There are very few studies on the spontaneous revegetation of cutover fens or bogs from which peat has been extracted to the minerotrophic layers. Most peatlands with fen-type residual peat have problems regenerating a plant cover satisfactory from a restoration point of view. We nevertheless found a site (Moss Spur, Manitoba, Canada) presenting a substantial and diversified spontaneous plant cover. We estimated that the site would provide insights about natural revegetation processes operating in peatlands. Vegetation assemblages and environmental conditions were surveyed 19 years after extraction activities ceased. Moss Spur has densely revegetated (163 plant species, vegetation cover of $94 \%$ ) with minimal human assistance. However, the composition of plant assemblages varied considerably across the site depending on certain abiotic variables, particularly water $\mathrm{pH}$, water table level, and the thickness of the residual peat layer. Moss Spur was remarkably wet considering its past peat extraction activities and the absence of active rewetting procedures. The high water table level may in part explain revegetation success. However, plant assemblages were not of equal quality from a restoration perspective. Some assemblages were highly diversified, and especially those dominated by Scirpus cyperinus, a species that should be further considered in peatland restoration projects to direct the recovery of the peatland towards a natural fen species composition.

Key words: Cyperaceae, Eriophorum vaginatum, fen, peatland restoration, Scirpus cyperinus, spontaneous revegetation, Trichophorum alpinum. 
Résumé : Il y a très peu de travaux sur la recolonisation végétale spontanée des tourbières où la tourbe $\mathrm{a}$ été extraite à des fins industrielles jusqu'aux couches minérotrophes. Le couvert végétal se rétablit difficilement dans de tels sites et ce qu'on y observe est rarement satisfaisant. Nous avons néanmoins trouvé une tourbière (Moss Spur, Manitoba, Canada) avec un couvert végétal substantiel et diversifié s'étant installé de manière naturelle après la fin des activités d'extraction. Nous avons estimé que ce site pourrait fournir des indices sur les processus favorisant la restauration des tourbières. Les données ont été récoltées 19 ans après la cessation de l'extraction de la tourbe. Le site de Moss Spur a été densément recolonisé par la végétation (163 espèces, couvert végétal de 94\%), malgré une absence presque totale de mesures de restauration. La composition des assemblages végétaux variait toutefois beaucoup au sein du site, selon la nature des caractéristiques en présence ( $\mathrm{pH}$ de l'eau, niveau de la nappe phréatique, épaisseur de la couche de tourbe). Le site de Moss Spur était toutefois particulièrement humide, ce qui peut expliquer en partie le couvert végétal observé. Les assemblages n'avaient néanmoins pas tous la même qualité sous l'angle de la restauration. Quelques-uns étaient particulièrement diversifiés, notamment ceux dominés par Scirpus cyperinus, une espèce qui devrait retenir davantage l'attention lors de futurs projets de restauration. L'usage de cette plante pourrait orienter un site vers une trajectoire aboutissant à une tourbière minérotrophe représentative de ce que l'on trouve en nature. 
Mots-clés : cypéracées, Eriophorum vaginatum, recolonisation végétale spontanée, restauration des tourbières, Scirpus cyperinus, Trichophorum alpinum, tourbière minérotrophe. 


\section{Introduction}

Spontaneous revegetation is the process by which a disturbed ecosystem that has lost its vegetation cover re-establishes a new plant cover, returning to either its initial state or another state, without human intervention. This phenomenon has been studied several times in peatlands that were used for peat extraction, a process requiring soil drainage and vegetation removal (Lavoie et al. 2003). After decades of extraction, the residual peat deposit is often no longer appropriate for the production of horticultural growing media, and the sites are closed from industrial activities. In Canada, until the 1990s, no restoration management was carried out on these sites. Under certain circumstances, natural revegetation processes were effective for restoring a plant cover (Gonzalez et al. 2013). Bare soils no longer remained, but most of the time, plant assemblages and hydrological and biogeochemical processes representative of peatlands were not restored this way. Poulin et al. (2005) found that Canadian peatlands where peat was manually extracted (up to the 1970s) had a higher plant cover than those that were mechanically (vacuum) extracted, because in the latter case, peat was drier and more compact at the end of extraction activities. Peatlands that were vacuum harvested had, even after many years, a poor plant cover with very little Sphagnum (Poulin et al. 2005; Graf et al. 2008). However, a few opportunistic vascular plant species sometimes took advantage of the new conditions and colonized the parched peat surface, often massively. This was particularly the case of tussock cottongrass (Eriophorum vaginatum), which may almost entirely cover the ground of certain peatlands (Lavoie et al. 2005a), a situation very rarely observed in undisturbed 
environments. Post-extraction peatlands were also vulnerable to colonization by trees such as grey birch (Betula populifolia), which accentuated water loss by evapotranspiration (Fay and Lavoie 2009).

No one relies, at least in North America, on spontaneous revegetation alone to assist the recovery of cutover bogs degraded by peat extraction. Highly effective ecological engineering techniques, such as the moss layer transfer technique, are now used to achieve this goal much faster (see Graf and Rochefort 2016 for the description of the mechanical operations). However, studying natural revegetation in peatlands helps to better understand how natural processes are operating for regenerating a site, and especially why these processes are in most case ineffective, which in turn provides insights on ways to better and faster restore highly disturbed peatlands.

Few researchers have studied the spontaneous revegetation of fens or bogs from which peat has been extracted to the minerotrophic layers. In North America, Cooper and MacDonald (2000) were among the first to study this topic. In Colorado, 43\% of the species found in disturbed fens were not considered representative of undisturbed fens. Plant richness was also lower in disturbed fens (30 species) than in fens that were not used for peat extraction (122). Graf et al. (2008), in their study on North American peatlands used for industrial purposes and having fen-type residual peat, noted a high density of vascular peatland plants in these sites, but a lack of Sphagnum and a low abundance (cover 1\%) of brown mosses (Amblystegiaceae or Calliergonaceae families) and Carex species. In Latvia, a fairly large proportion of plants in disturbed peatlands with minerotrophic conditions were not peatland-specific (Priede et al. 2016). In summary, peatlands with fen-type residual 
peat have, just like bogs, problems regenerating a plant cover similar to regional fen reference ecosystems.

During a survey of post-extraction peatlands of Manitoba (Canada), we visited a fenlike site (Moss Spur) with a substantial and highly diversified spontaneous plant cover. We estimated that this site would provide insights about natural revegetation processes operating in peatlands, and could potentially open avenues for restoring peatlands at lower cost. Specifically, the aims of this project were to 1) describe the plant assemblages which established spontaneously, 2) associate abiotic and landscape characteristics to these assemblages, and 3) qualify the different assemblages observed from an ecological restoration point of view. We hypothesized that 1) revegetation in this peatland was dominated by wetland species, particularly from fens, and not from bogs or Sphagnumdominated peatlands, 2) water table was the main factor explaining the differences observed between the assemblages, and 3) the closer the water table was to the soil surface, the more the plant cover resembled that of a fen. In other words, we predicted that a water table too high (well above the soil surface) or too low (well below the soil surface) resulted in plant assemblages that were not representative of peatlands (fens or bogs). The other hypothesis we tested was that 4) $\mathrm{pH}$ and water conductivity were the other variables that best explained assemblage composition, after water table level. Based on the work of Andersen et al. (2011), we predicted that low pH $(\sim 4,0)$ and low electrical conductivity $\left(\sim 57 \mu \mathrm{sm}^{-1}\right)$ locally favoured the return of Sphagnum-dominated peatland species, whereas high pH $(>5,2)$ and high electrical conductivity $\left(>80 \mu \mathrm{sm}^{-1}\right)$ favoured fen species. 


\section{Materials and methods}

\section{Study site}

The Moss Spur peatland is located in southeast Manitoba $\left(49^{\circ} 59^{\prime} \mathrm{N}, 96^{\circ} 08^{\prime} \mathrm{W}\right)$, about $60 \mathrm{~km}$ east of Winnipeg. Its mean altitude is $280 \mathrm{~m}$. The peatland is located at the junction of the Canadian Shield and the Interior Plains. It is inserted in a large peatland complex, which extends over hundreds of square kilometers. The closest meteorological station, PINAWA WNRE (Environment Canada 2014), is located $20 \mathrm{~km}$ north of the peatland. The mean annual temperature is $3{ }^{\circ} \mathrm{C}$. The mean temperature of the coldest month is $-17^{\circ} \mathrm{C}$ (January) and $19{ }^{\circ} \mathrm{C}$ for the warmest month (July). Annual mean precipitation is $578 \mathrm{~mm}$, of which $464 \mathrm{~mm}$ fall as rain.

The peat extraction zone was originally ombrotrophic, and Sphagnum-dominated, with a domed profile. Peat was extracted over an area of 430 ha, from 1936 to 1999 (Fig. 1). The extraction zone is crossed by a railway (constructed in the 1880s) and a dirt road (constructed between 1955 and 1970). The extraction was first done by hand, using shovels, then by mechanical methods (milled and vacuum-harvested) a few years before 1970 and afterwards. Use of the northern part of the site (north of the road) ceased following an accidental fire in 1995, which burned down the factory as well as a large part (25\%) of the extraction zone, essentially south of the road. Extraction of the southern section ceased in 1999. Despite the end of peat extraction activities, some drainage canals are still in operation, because they drain another peatland to the southwest, which is still used for industrial purposes. Many beavers have taken up residence on site and erected 
dams across some drainage canals, which probably reduces the effectiveness of the ditches. A significant portion of the site (around 30\%) is flooded throughout the summer.

\section{Sampling}

Recent satellite images of the peatland (Google Earth 2014) were geolocated and integrated in a geographic information system (ArcGIS; ESRI 2015). For the purpose of this study, the peatland was subdivided into 24 sectors separated by the main drainage ditches (Fig. 1). This subdivision produced sectors of unequal size, but whose borders were easily identifiable on the ground. A total of 97 vegetation quadrats and 47 water level observation wells were distributed among the sectors according to the length of their respective longest side. Only half the quadrats had a well: the measurement of all water table levels had to be accomplished over two or three days at most, in order to avoid abrupt water level fluctuations caused by a sustained drought or a sudden torrential rain, phenomena which could hinder data comparison between wells. It was therefore not possible to place a well at each quadrat, as collecting a series of data for 97 wells would have required nearly a week because of accessibility problems on the ground. However, the quadrat configuration permitted, thanks to the kriging function of ArcMap in ArcGIS, to extrapolate the data between wells, and thus associate a water table level to each vegetation quadrat for a given data series. The exact location of the quadrats and wells was determined using the GIS by drawing a line that followed the center of the sector along its entire length. The quadrats and wells were then spaced along this line leaving an equal distance between each of them. 


\section{Data collection}

Data collection occurred between 18 June and 7 August 2014. A grid with a $1 \mathrm{~m}$ spacing was placed in each quadrat $(9 \times 9 \mathrm{~m})$. At each grid intersection (total: 100 per quadrat), a 5-cm diameter rod was planted vertically in the soil and all plant species touching the rod were noted, with the exception of liverworts and lichens, for which only the presence was noted without identifying the species. Given that the cattail growth stage was sometimes insufficiently advanced during data collection, it was not always possible to differentiate the two Typha species (T. latifolia and T. angustifolia) in the field. These two species were therefore grouped under the taxon Typha throughout data analysis. For each quadrat, the peat depth was measured at two opposing corners by driving a metal rod into the organic soil until the underlying mineral soil was reached. In addition, $\mathrm{pH}$ and water electrical conductivity were measured using a portable $\mathrm{pH}$-conductivity meter. As the water table was generally high on the site, it was always possible to dig a shallow hole to sample water below the soil surface. A peat sample was also taken at the soil surface of each quadrat to (1) measure in laboratory its pH (saturated media extraction), (2) determine the degree of peat decomposition using the pyrophosphate test (Soil Classification Working Group 1998), (3) measure the total Ca concentration (Parkinson and Allen 1975), as well as (4) the composition of the peat by visual examination under a lowpower (50×) stereomicroscope (dominated by Sphagnum, brown moss, herbaceous plant and/or woody remains). The water table level was measured twice in wells, 28-29 July and 6-7 August. Between 28 July and 7 August, $3 \mathrm{~mm}$ of rain fell, and daily temperatures varied between maxima of 22 to $29^{\circ} \mathrm{C}$ and minima of 8 to $17^{\circ} \mathrm{C}$. Water table measurements were 
subsequently separated into two groups, comprising either the minimum or maximum values measured (or estimated by kriging) for each quadrat. The difference between these values was also calculated to provide an estimation of water level fluctuations over a short period of time.

Other data were compiled using historical documents and GIS. Aerial photographs of the site (scale: 1:16,000) taken in 1948, 1955, 1970, 1983, 1996, 1997 and 2011 (Canada Map Sales 2014) were used. The year corresponding to the beginning of the extraction period at the location of each quadrat was estimated using the photographs. The year was estimated by taking the median year between the most recent photograph showing no extraction activities and the following photograph with clear evidence that extraction had begun in a given sector. Testimony of an employee who worked at the peatland site, and information obtained from the peat company, further clarified the extraction period for different sectors. The photographs were also used to identify the extraction method for each sector (manual or mechanical), for each period. The GIS was used to calculate the shortest distance between a quadrat and the railway and the nearest extraction zone border. Finally, because a railway built through a peatland can hydrologically isolate both sides (Van Seters and Price 2001), a variable with a value of 1 (north of the railway) or 0 (south of the railway) was associated to each quadrat according to its location.

\section{Variables}

Vegetation data consisted of frequency of occurrences by species and by quadrat. The taxonomic nomenclature follows that proposed by the Flora of North America Editorial 
Committee (1993+) for vascular plants, and Société québécoise de bryologie (2017) for bryophytes. Various publications were used to associate a habitat (bog, fen, marsh/swamp, dry habitat) to each plant species surveyed. The abiotic variables measured in each quadrat were the (1) pH of water ( $p H$ water) and (2) of the peat ( $p H$ peat), (3) electrical conductivity of ground water corrected for $\mathrm{pH}$ (conductivity), (4) the minimum water table level (water $\mathrm{min}$ ), which meant the farthest from the soil surface, (5) the maximum water table level (water max), which meant the closest to the surface, (6) the difference between these levels (water dif), (7) the total Ca concentration of the peat (Ca total), (8) the peat pyrophosphate index (pyrophosphate), (9) the residual peat thickness (peat), and two binary variables indicating whether the peat surface was mainly composed with plant remains of (10) Cyperaceae (Cyperaceae) or (11) Sphagnum (Sphagnum). The spatiotemporal data associated to each quadrat included four other variables, i.e., (12) the approximate year when peat extraction was initiated (extraction start), (13) the shortest distance between the quadrat and the railway (railway), (14) the shortest distance between the quadrat and the nearest extraction zone border (border), and (15) a nominal variable indicating the location (north or south) of the quadrat with regards to the railway (north/south).

\section{Statistical analyses}

A cluster analysis was performed to group quadrats using species composition as the distinguishing criterion. The Caliński-Harabasz index (Caliński and Harabasz 1974) was used to determine the optimal number of groups prior to the analysis (three in this case). 
The partition was made by $K$-means partitioning, an agglomerative method that maximizes similarities within each group (Jain and Dubes 1988). Ordination calculations were conducted to associate quadrats, species and abiotic and spatio-temporal variables. To visually represent the similarity of quadrats with regards to species composition, a principal component analysis (PCA) was performed. The effect of the environmental variables on the species composition of quadrats was taken into account by a redundancy analysis (RDA). The quadrat-species matrix underwent a Hellinger transformation prior to the RDA calculation to avoid the double-zero problem (Legendre and Gallagher 2001). The RDA was then conducted by first forward-selecting the variables that significantly contributed to the model. A second RDA was calculated using only the selected variables. Variables removed from the RDA were peat $p H$, conductivity, water max, Ca total, pyrophosphate, Cyperaceae and Sphagnum. Finally, a permutation test (1000 permutations) was used to test the significance of the analysis (Legendre and Legendre 2012). All statistical tests were carried out in version 3.2.1 of R software (R Core Team 2016) using the fpc (Henning 2014) and vegan (Oksanen et al. 2016) packages. The Shannon's diversity index (Magurran 1988) was also calculated for the different vegetation assemblages found in the peatland. 


\section{Results}

\section{Peat extraction history}

Peat extraction began around 1936 in sectors E and F of Moss Spur (Fig. 1). Most of the sectors were used in the 1950s and 1960s. Extraction activities in the last sector to be harvested (J) began around 1987. Ultimately, the different sectors were used over periods ranging from 3 to 54 years, but these durations remain approximate given the lack of precision regarding the years when work started and finished. Sampling quadrats in the different sectors were located at widely varying distances from the edge (between 61 and $909 \mathrm{~m}$ ) or from the railway (between 95 and $1340 \mathrm{~m}$ ).

\section{Overview of the vegetation}

Between 15 to 20 years after the end of extraction activities at Moss Spur, 94\% of the vegetation sampling points (all quadrats) were occupied by at least one plant species. A total of 137 species, grouped into 41 vascular and bryophyte plant families, were identified. Of the 137 plant species found, 46 (34\%) were bryophytes. There were, on average, 18 plant species (vascular plants and bryophytes) per quadrat (minimum 2, maximum 39). The peatland was dominated by Cyperaceae species. The 27 species from this family together had a mean frequency of occurrence of $81 \%$, with four species particularly well represented, i.e., Trichophorum alpinum (34\%), Eriophorum vaginatum (23\%), Scirpus cyperinus (14\%) and Rhynchospora alba (13\%). Bryophytes were present at $24 \%$ of the sampling points, mainly Polytrichum strictum (5\%), Aulacomnium palustre (4\%) and 
Campylium stellatum (4\%). Most species identified at Moss Spur were representative of wetlands (all types combined). Here, wetlands are defined as lands that are saturated with water long enough to promote aquatic processes, as indicated by poorly drained soils, hydrophytic vegetation, and various kinds of biological activity which are adapted to a wet environment. They include bogs, fens, marshes, swamps and shallow waters (National Wetlands Working Group 1988). Among wetland species, 21\% were mainly associated to bogs and 38\% to fens. Vegetation cover was 93\% wetland species (all types), 39\% bog plants and 58\% fen plants (Table 1; see Gagnon 2017 for the complete list of plant species).

\section{Plant assemblages}

The sampling quadrats were clustered into three groups $(\mathrm{G})$ by the vegetation cluster analysis. There were large differences in species composition between these groups (Table 1 and 2, Fig. 2). Most species of G1 (Scirpus group) were marsh/swamp species (Calamagrostis canadensis, Carex canescens, Phragmites australis, Typha spp., Salix bebbiana), with Scirpus cyperinus as the most common plant. The G1-Scirpus quadrats had the highest Shannon's diversity index. The most common species at Moss Spur, Trichophorum alpinum, was mainly found in the G2 quadrats (frequency of occurrence: 77\%). G2 (Trichophorum group) was dominated by fen species (Campylium stellatum, Rhynchospora alba and T. alpinum), accompanied by a few bog (Drosera rotundifolia and Vaccinium oxycoccos) and marsh/swamp species (C. canescens and S. cyperinus). The frequency of occurrence of Eriophorum vaginatum was highly contrasted between the groups. A high percentage (82\%) was found in G3 (Eriophorum group), whereas the 
frequency was very low (4\%) in G1-Scirpus and G2-Trichophorum. G3-Eriophorum was mainly covered by species primarily found in disturbed peatlands with bog conditions (D. rotundifolia, E. vaginatum, Polytrichum strictum and V. oxycoccos), but also harbored marsh/swamp (C. canescens, Larix laricina and S. cyperinus) and fen species (Betula pumila and Polytrichum commune), and one species (Betula papyrifera) not representative of wetlands.

The PCA clearly segregated the G3-Eriophorum quadrats from the G1-Scirpus and G2Trichophorum quadrats, the last two groups being arranged on both sides of a long continuous band (Fig. 3). This analysis illustrated 59\% of the variation from the species composition between quadrats. As expected, Eriophorum vaginatum was strongly associated with G3, whereas Scirpus cyperinus and Typha spp. were associated with G1, and Trichophorum alpinum and Rhynchospora alba with G2, respectively.

A little more than $29 \%$ of the species composition variation was explained by the RDA (Fig. 4), and the model was significant $(\mathrm{p}<0.001)$. Eight explanatory variables were retained for the model. The quadrats within each group were roughly aligned on the plane formed by the first two axes of the analysis. G1-Scirpus quadrats were associated with a high water $p H$, a high water dif and a thin peat. G2-Trichophorum quadrats were distinguished by a thick peat, a low water dif, a high water min, a large border, and a relatively early onset of peat extracting activities (later extraction start). G3-Eriophorum were generally far from the railway and close to edge, and had rather acidic water $p H$ and a low water min (Table 2 ). 


\section{Abiotic variables}

Water table levels ranged from $44 \mathrm{~cm}$ below the soil surface to $23 \mathrm{~cm}$ above the surface (Fig. 5a). The wettest sectors were in the northwest and center, whereas the driest sectors were mostly in the southwest and northeast. Locally, the smallest difference in water level between both measurement periods was $1 \mathrm{~cm}$, and the largest $13 \mathrm{~cm}$ (Fig. $5 \mathrm{~b}$ ). The largest differences in water levels were recorded where the water table was lowest (southwest). The residual peat layer across the peatland varied from 83 to $300-\mathrm{cm}$ thick (Fig. 5c). Sectors with the thickest layer were concentrated along a strip running northwest to southeast across the site. Water $\mathrm{pH}$ (4.3-6.9) was generally more acidic around the edges of the peatland than at the center (Fig. 5d). Total Ca concentration tended to increase with peat $\mathrm{pH}$, and the values were between $3.7 \mathrm{mg} \mathrm{g}^{-1}$ and $21.5 \mathrm{mg} \mathrm{g}^{-1}$. Electrical conductivity of water varied between 31 and $257 \mu \mathrm{S} \mathrm{cm}^{-1}$. The lowest pyrophosphate index was 3, the highest 7. Because the spatial patterns of total $\mathrm{Ca}$, electrical conductivity of water and pyrophosate index were similar to that of water $\mathrm{pH}$, their maps are not presented.

\section{Discussion}

\section{Moss Spur site as a whole}

With 163 plant species over the cutover bog, 94\% of the sampling points covered by vegetation and an average species richness of 18 species per quadrat $\left(81 \mathrm{~m}^{2}\right)$, Moss Spur has densely revegetated with minimal human assistance, i.e., a few ditches blocked at undetermined places. However, the composition of plant assemblages varied considerably across the site depending on certain abiotic variables, particularly water $\mathrm{pH}$, water table 
level, and the thickness of the residual peat layer, and these assemblages were not of equal quality from a restoration perspective.

The current vegetation of Moss Spur is probably very different from that existing before the start of peat extraction, when this section of the peat complex was shaped like an ombrotrophic (bog) island (dome). Nineteen years after extraction ceased, $82 \%$ of the species growing on the site were representative of wetlands, although only half (49\%) were associated to peatlands (18\% bogs, $31 \%$ fens). That said, fen species covered the greatest area of the site. From this perspective, Moss Spur revegetated very differently from its initial state, assuming, of course, that the original vegetation was ombrotrophic and Sphagnum-dominated, a highly probable hypothesis in spite of the absence of historical field data, as the horticultural peat company was only interested in extracting Sphagnum peat mosses. The hypothesis that the vegetation cover at Moss Spur is now dominated by wetland vegetation, in particular fen rather than bog species, is therefore verified, even though a large area of the site has been colonized by species primarily found in disturbed peatlands with bog conditions (Girard et al. 2002; Lavoie et al. 2003; 2005a, $b$; Poulin et al. 2005).

The three groups of quadrats surveyed had distinct plant assemblages and were located at different places along the environmental gradients of Moss Spur. Water pH formed the strongest gradient among those measured and allowed a particularly good distinction between G1-Scirpus and G2-Trichophorum quadrats from those of G3Eriophorum, which had more acidic water than the two other groups. Two other environmental variables helped to differentiate G1-Scirpus from G2-Trichophorum. G1- 
Scirpus seemed to experience slightly larger water table fluctuations, while G2Trichophorum had a thicker residual peat layer.

The importance of water table as explanatory variable for plant assemblages was not as clearly highlighted by our analyses as initially hypothesized, or as found by Vitt et al. (2016) for peat-forming wetlands reclaimed after open-pit mining of oil sands (Alberta, Canada), where water level controlled the spatial distribution of plant assemblages. Caution must be exercised with respect to water table as the estimates were based on two sets of data taken eight to nine days apart, which was insufficient for drawing strong conclusions regarding the effect of water table at Moss Spur. However, it appears that at this site, the problem is less a lack of water -a situation common in peatlands where peat was industrially extracted (Haapalehto et al. 2014; Malloy and Price 2014; McCarter and Price 2014)- than conditions of flooding, particularly at G1-Scirpus sites dominated by cattails. Likewise, in a recovering reclaimed fen site in Alberta, marsh species were especially abundant in the wettest areas (Vitt et al. 2016). In fact, the water table was high across the site, and in the summer of 2014 was virtually never less than $28 \mathrm{~cm}$ below the soil surface. This site was remarkably wet considering its past peat extraction activity and the absence of formal restoration procedures. The most plausible explanation for the area to be prone to flooding is that the relatively flat topography slows the peatland drainage, compounded by many drainage canals which no longer appear functional, and the drainage obstruction caused by the road and beaver dams. It is also possible that the sectors with a water level well above the surface corresponded to depressions in the peatland topography, whether natural or from industrial activities (Girard et al. 2002); G1-Scirpus 
were associated with the thinnest peat deposits, so where depressions were potentially located. This situation probably explains in part the high wetland plant cover at Moss Spur, but most bog plants, and to a lesser extent fen plants, do not tolerate water levels well above the soil surface (Andrus et al. 1983, Gignac et al. 2004). In summary, part of our initial prediction (a too high water table, i.e., above the soil surface for the major part of the growing season, results in plant assemblages not representative of peatlands) seems accurate. The other part, i.e., that a too low water table has the same effect, could not be verified, since this situation did not occur in the field. Indeed, a water table $>40 \mathrm{~cm}$ below the soil surface had not been measured at Moss Spur. This 40-cm value is often considered as a threshold below which Sphagnum cover restoration is seriously compromised in cutover bogs (Ketcheson and Price 2001, Price and Whitehead 2001).

A parallel may be traced between the types of plant assemblages and the $\mathrm{pH}$ and electrical conductivity values of the water. G1-Scirpus and G2-Trichophorum were similar to fen types of wetlands and had the highest $\mathrm{pH}$ (5.3-5.7) and electrical conductivity values (119-126 s cm$^{-1}$ ). G3-Eriophorum was colonized by plants from Sphagnum-dominated peatlands, especially those that have been disturbed, and had the lowest pH (4.6) and electrical conductivity $\left(126 \mu \mathrm{s} \mathrm{cm}^{-1}\right)$ of the three groups. The hypothesis that lower $\mathrm{pH}$ and electrical conductivity locally favour the presence of Sphagnum-dominated peatland species, while a high pH and electrical conductivity favour fen species, is thus verified. 


\section{The three Moss Spur plant assemblages}

The G1-Scirpus quadrats had the highest Shannon's diversity index, meaning they contained many plant species with relative abundances well distributed among the species. The plant assemblages of this group were dominated either by Scirpus cyperinus or Typha species (cattails). The dominance of S. cyperinus in this group is not necessarily surprising. This species is known to cover disturbed peatlands with minerotrophic conditions in North America while being less abundant in undisturbed fens and bogs (Graf et al. 2008). Scirpus cyperinus has been considered by some peat restoration specialists as an undesirable species, because although it establishes rapidly and densely on disturbed sites, it tends to form monospecific stands and do not help to recreate a diverse plant assemblage (Graf et al. 2008; Lajoie 2015). However, this characteristic of the plant was not supported by our data since G1-Scirpus was the group which, on average, displayed the highest Shannon's index. In addition, this bulrush species decomposes slowly (Graf and Rochefort 2009), and has consequently a peat accumulation potential that could help to restore the positive carbon balance of a peatland. The species may have a higher value for peatland restoration than previously thought.

Cattails are not representative of peatlands, at least in great abundance. Cattails, particularly Typha xglauca and T. angustifolia, tend to be invasive in North American wetlands. Typha populations are increasing, especially in eastern North America (Shih and Finkelstein 2008), and over time, they reduce plant diversity (Mitchell et al. 2011). However, cattails may have been present at an earlier stage in the peatland. Early in their formation, continental Canadian peatlands generally go through a stage of ponds colonized 
by cattails, these plant contributing to the accumulation of peat. It is thus possible that the peat extraction at Moss Spur turned back the clock of ecological succession to the beginning of the peat accumulation period, a jump back of around 2000 to 3000 years (Kuhry et al. 1993).

The absence of Sphagnum carpets and the prevalence of fen species made G2Trichophorum similar to rich and moderate-rich fens (Campbell and Rochefort 2001). G2Trichophorum had dense populations of Trichophorum alpinum and Rhynchospora alba. Trichophorum alpinum is a circumboreal species (Flora of North America Editorial Committee, 2003) known to colonize mainly fens, but also bogs (Anderson et al. 1996). Its tolerance to a wide pH spectrum (Gignac et al. 2004) probably in part explains its high abundance. The tolerance of T. alpinum to a wide range of conditions and its frequency of occurrence at Moss Spur highlights its ability to occupy a disturbed peatland, and indicates that it may be a useful species for restoration projects.

Rhynchospora alba, a poor competitor, generally grows on muddy substrates in ombrotrophic peatlands (Ohlson and Malmer 1990; Karofeld et al. 2015). This species adapts to acidic $\mathrm{pH}$ levels and grows mainly where the water table is between 10 and $20 \mathrm{~cm}$ below the surface (Gignac et al. 2004). The frequency of occurrence of $R$. alba was positively influenced by a thick residual peat layer. Moreover, on the study site, this plant tended to grow where the peat was strongly decomposed and wet. Such conditions are similar to those found on muddy substrates. Rhynchospora alba could be a good plant to introduce in a disturbed peatland if the goal is to restore a Sphagnum carpet. It has been 
observed that $R$. alba precedes Sphagnum establishment, probably due to a facilitation effect (Karofeld et al. 2015).

The G3-Eriophorum plant assemblages were probably closest to the initial state of the peatland before extraction (beginning of the 20th century) with regards to abiotic conditions. The plant communities were similar to those found in bogs having undergone extraction activities and where surface conditions are still ombrotrophic (Lavoie et al. 2005b; Poulin et al. 2005). Much more Sphagnum was found in G3-Eriophorum than in the other plant groups. The presence of Sphagnum in wetlands is generally indicative of acidic poor fen or bog conditions. Some quadrats were covered with an extensive Sphagnum carpet, i.e., with a frequency of occurrence up to $90 \%$, all species combined. The few cases were Sphagnum occurrence was very high were remarkable given that vacuum harvested peatlands generally have a very low Sphagnum cover, even many years after extraction activities cease (Poulin et al. 2005; Graf et al. 2008). It is possible that high water acidity at the G3-Eriophorum quadrats favoured the establishment of bog species. Following establishment, Sphagnum plants then probably contributed to further acidification (van Breemen 1995; Campbell and Rochefort 2001).

This study showed that a cutover bog of more than 400 ha within a lowland peatland complex has become a wetland habitat composed of a mosaic of fen and bog conditions, by the means of rewetting and spontaneous revegetation. The main factors influencing the establishment of plant assemblages were the water level and the prevailing $\mathrm{pH}$ of the cutover sector. The diversity of residual organic soils following the extracting activities produced different peatland habitats comprising a great diversity of wetland 
plants (up to 113 species), 66 of which being peatland plants. The implication of this study for future peatland management is that a general level of predictions could be done when post-extraction peat activities result in Cyperaceae peat residual substrate, in a site located in an extensive lowland wetland complex. Planning rewetting actions to target specific water level ranges associated with different $\mathrm{pH}$ of the substrate could potentially lead to the spontaneous establishment of plant peat accumulating assemblages, a first step toward the restoration of the carbon sequestration capabilities of the site, a key function of peatland ecosystems.

\section{Acknowledgements}

This research was financially supported by the Natural Sciences and Engineering Research Council of Canada and the Canadian Sphagnum Peat Moss Association and its members. SunGro Horticulture provided access to the study site and strong logistic support. We thank Elisabeth Groeneveld and Jonathan Rosset for field assistance, and Thierry Dutoit, Sylvain Jutras and Christian Lacroix for comments on an earlier draft. 


\section{References}

Andersen, R., Rochefort, L., and Landry, J. 2011. La chimie des tourbières du Québec: une synthèse de 30 années de données. Nat. Can. (Que) 135(1): 5-14.

Anderson, D.S., Davis, R.B., Rooney, S.C., and Campbell, C.S. 1996. The ecology of sedges (Cyperaceae) in Maine Peatlands. Bull. Torrey Bot. Club, 123(2): 100-110. doi: $10.2307 / 2996067$.

Andrus, R.E., Wagner, D.J. and Titus, J.E. 1983. Vertical zonation of Sphagnum mosses along hummock-hollow gradients. Can. J. Bot. 61(12): 3128-3139. doi:101139/b83-352.

Caliński, T., and Harabasz, J. 1974. A dendrite method for cluster analysis. Commun. Stat. 3(1): 1-27.

Campbell, D.R., and Rochefort, L. 2001. La végétation : gradients. In Écologie des tourbières du Québec-Labrador. Edited by S. Payette and L. Rochefort. Les Presses de l'Université Laval, Québec, Que. pp. 129-140.

Canada Map Sales. 2014. Moss Spur. Manitoba Conservation, Winnipeg, Man.

Cooper, D.J., and MacDonald, L.H. 2000. Restoring the vegetation of mined peatlands in the southern Rocky Mountains of Colorado, U.S.A. Restor. Ecol. 8(2): 103-111. doi:10.1046/j.1526-100x.2000.80016.x.

Crow, G.E., and Hellquist, B. 2000. Aquatic and wetlands plants of northeastern North America. University of Wisconsin Press, Madison, Wisconsin.

Environment Canada. 2014. 1981 - 2010 climate normals and averages. Available from http://climat.meteo.gc.ca/climate_normals/index_e.html [accessed 2 October 2014]. 
ESRI. 2015. ArcGIS Desktop: release 10. Environmental Systems Research Institute, Redlands.

Faubert, J. 2013, 2014. Flore des bryophytes du Québec-Labrador. Société québécoise de bryologie, Saint-Valérien, Que.

Fay, E., and Lavoie, C. 2009. The impact of birch seedlings on evapotranspiration from a mined peatland: an experimental study in southern Quebec, Canada. Mires and Peat, 5(article 03): 1-7.

Flora of North America Editorial Committee. 1993+. Flora of North America north of Mexico. Flora of North America Editorial Committee, New York and Oxford.

Gagnon, F. 2017. La régénération spontanée d'une tourbière manitobaine après extraction de la tourbe : diversité des assemblages végétaux et propositions d'aménagement. M.ATDR thesis, École supérieure d’aménagement du territoire et de développement régional, Université Laval, Québec, Que. Available from https://corpus.ulaval.ca/jspui/handle/20.500.11794/27477 [accessed 28 May 2018].

Garneau, M. 2001. Statut trophique des taxons préférentiels et des taxons fréquents mais non préférentiels des tourbières naturelles du Québec-Labrador. In Écologie des tourbières du Québec-Labrador. Edited by S. Payette and L. Rochefort. Les Presses de l’Université Laval, Québec, Que. pp. 523-531.

Gignac, L.D., Gauthier, R., Rochefort, L., and Bubier, J. 2004. Distribution and habitat niches of 37 peatland Cyperaceae species across a broad geographic range in Canada. Can. J. Bot. 82(9): 1292-1313. doi:10.1139/b04-081. 
Girard, M., Lavoie, C., and Thériault, M. 2002. The regeneration of a highly disturbed ecosystem: a mined peatland in southern Québec. Ecosystems, 5(3): 274-288. doi:10.1007/s10021-001-0071-7.

González, E., Rochefort, L., and Poulin, M. 2013. Trajectories of plant recovery in block-cut peatlands 35 years after peat extraction. Appl. Ecol. Env. Res. 11(3): 385-406.

Google Earth. 2014. Moss Spur, Manitoba. 4959’14”N, 9607’55”W. Available from https://earth.google.com/web [accessed 5 May 2014].

Graf, M.D., and Rochefort, L. 2009. Examining the peat-accumulating potential of fen vegetation in the context of fen restauration of harvested peatlands. Écoscience, 16(2):158-166. doi:10.2980/16-2-3128.

Graf, M.D., and Rochefort, L. 2016. A conceptual framework for ecosystem restoration applied to industrial peatlands. In Peatland restoration and ecosystem services: science, policy and practice. Edited by S.A. Bonn, T. Allott, M. Evans, H. Joosten and R. Stoneman. Cambridge University Press, Cambridge, UK. pp. 192-212.

Graf, M.D., Rochefort, L., and Poulin, M. 2008. Spontaneous revegetation of cutaway peatlands of North America. Wetlands, 28(1): 28-39. doi:10.1672/06-136.1.

Haapalehto, T., Kotiaho, J.S., Matilainen, R., and Tahvanainen, T. 2014. The effects of longterm drainage and subsequent restoration on water table level and pore water chemistry in boreal peatlands. J. Hydrol. 519: 1493-1505. doi:10.1016/j.jhydrol.2014.09.013.

Hennig, C. 2015. Fpc: flexible procedures for clustering. R package version 2.1-10. Available from http://CRAN.R-project.org/package=fpc [accessed 24 March 2018]. 
Jain, A.K., and Dubes, R.C. 1988. Algorithms for clustering data. Prentice Hall, Englewood Cliffs, New Jersey.

Karofeld, E., Rivis, R., Tõnisson, H., and Vellak, K. 2015. Rapid changes in plant assemblages on mud-bottom hollows in raised bog: a sixteen-year study. Mires and Peat, 16(article 11): 1-13.

Ketcheson, S.J., and Price, J. 2011. The impact of peatland restoration on the site hydrology of an abandoned block-cut bog. Wetlands, 31(6): 1263-1274. doi:10.1007/s13157-0110241-0

Kuhry, P., Nicholson, B.J., Gignac, L.D., Vitt, D.H. and Bayley, S.E. 1993. Development of Sphagnum-dominated peatlands in boreal continental Canada. Can. J. Bot. 71(1): 10-22. doi: 10.1139/b93-002.

Lajoie, J. 2015. Le Scirpus cyperinus. Germination, établissement et compétition en contexte de restauration de fen. Université Laval, Québec. M.Sc. thesis, Département de phytologie, Université Laval, Québec, Que.

Lavoie, C., Grosvernier, P., Girard, M., and Marcoux, K. 2003. Spontaneous revegetation of mined peatlands: an useful restoration tool? Wetlands Ecol. Manage. 11(1-2): 97-107. doi.org/10.1023/A:1022069808489.

Lavoie, C., Marcoux, K., Saint-Louis, A., and Price. J.S. 2005a. The dynamics of a cotton-grass (Eriophorum vaginatum L.) cover expansion in a vacuum-mined peatland, southern Québec, Canada. Wetlands, 25(1): 64-75. doi:10.1672/02775212(2005)025[0064:TDOACE]2.0.CO;2. 
Lavoie, C., Saint-Louis, A., and Lachance, D. 2005b. Vegetation dynamics on an abandoned vacuum-mined peatland: 5 years of monitoring. Wetlands Ecol. Manage. 13(6): 621-633. doi:10.1007/s11273-005-0126-1.

Legendre, P. and Gallagher, E. 2001. Ecologically meaningful transformations for ordination of species data. Oecologia, 129(2): 271-280. doi :10.1007/s004420100716.

Legendre, P., and Legendre, L. 2012. Numerical ecology. 3rd edition. Elsevier Science BV, Amsterdam.

Lichvar, R.W., Butterwick, M., Melvin, N.C., and Kirchner, W.N. 2014. The national wetland plant list: 2014 update of wetland ratings. Phytoneuron, 41: 1-42.

Magurran, A.E. 1988. Ecological diversity and its measurement. Princeton University Press, Princeton, New Jersey.

Malloy, S., and Price, J.S. 2014. Fen restoration on a bog harvested down to sedge peat: a hydrological assessment. Ecol. Eng. 64: 151-160. doi:10.1016/j.ecoleng.2013.12.015.

McCarter, C.P.R., and Price, J.S. 2014. The hydrology of the Bois-des-Bel peatland restoration: hydrophysical properties limiting connectivity between regenerated Sphagnum and remnant vacuum harvested peat deposit. Ecohydrology, 8(2): 173-187. doi:10.1002/eco.1498.

Mitchell, M.E., Lishawa, S.C., Geddes, P., Larkin, D.J., Treering, D., and Tuchman, N.C. 2011. Time-dependent impacts of cattail invasion in a Great Lakes coastal wetland complex. Wetlands, 31(6): 1143-1149. doi:10.1007/s13157-011-0225-0.

National Wetlands Working Group. 1988. Wetlands of Canada. Environment Canada and Polyscience Publications, Montréal, Que. 
Ohlson, M., and Malmer, N. 1990. Total nutrient accumulation and seasonal variation in resource allocation in the bog plant Rhynchospora alba. Oikos, 58(1): 100-108. doi:10.2307/3565365.

Okasen, J.F., Blanchet, G., Friendly, M., Kindt, R., Legendre, P., McGlinn, D., Minchin, P.R., O’Hara, R.B., Simpson, G.L., Solymos, P., Stevens, M.H.H., Szoecs, E., and Wagner, H. 2015. Vegan: community ecology package. R package version 2.3-2. Available from http://CRAN.R-project.org/package=vegan [accessed 24 March 2018].

Parkinson, J.A., and Allen, S.E. 1975. A wet oxidation procedure suitable for determination of nitrogen and mineral nutrients in biological material. Commun. Soil Sci. Plant Anal. 6(1): 1-11. doi:10.1080/00103627509366539.

Poulin, M., Rochefort, L., Quinty, F., and Lavoie, C. 2005. Spontaneous revegetation of mined peatlands in eastern Canada. Can. J. Bot. 83(5): 539-557. doi:10.1139/b05-025.

Price, J.S., and Whitehead G.S. 2001. Developing hydrologic thresholds for Sphagnum recolonization on an abandoned cutover bog. Wetlands, 21(1): 32-40. doi:10.1672/0277-5212(2001)021[0032:DHTFSR]2.0.CO;2.

Priede, A., Mežaka, A., Dobkeviča, L., and Grīnberga, L. 2016. Spontaneous revegetation of cutaway fens: can it result in valuable habitats? Mires and Peat, 18(article 06): 1-14. doi:10.19189/MaP.2016.0MB.220.

R Core Team. 2016. R: a language and environment for statistical computing. R version 3.2.5. R Foundation for Statistical Computing, Vienna. 
Shih, J.G., and Finkelstein, S.A. 2008. Range dynamics and invasive tendencies in Typha latifolia and Typha angustifolia in eastern North America derived from herbarium and pollen records. Wetlands, 28(1): 1-16. doi:10.1672/07-40.1.

Société québécoise de bryologie. 2017. Liste des taxons présents au Québec-Labrador. Available from http://www.societequebecoisedebryologie.org/bryoquel.html [accessed 16 May 2018].

Soil Classification Working Group. 1998. The Canadian system of soil classification. 3rd edition. Agriculture and Agri-Food Canada Publication, Ottawa, Ont.

van Breemen, N. 1995. How Sphagnum bogs down other plants. Trends Ecol. Evol. 10(7): 270-275. doi:10.1016/0169-5347(95)90007-1.

Van Seters, T.E., and Price, J.S. 2001. The impact of peat harvesting and natural regeneration on the water balance of an abandoned cutover bog, Quebec. Hydrol. Processes, 15(2): 233-248. doi:10.1002/hyp.145.

Vitt, D.H., House, M., and Hartsock, J.A. 2016. Sandhill Fen, an initial trial for wetland species assembly on in-pit substrates: lessons after three years. Botany, 94(11): 1015-1025. doi.org/10.1139/cjb-2015-0262. 
Table 1. Overview of the plants of the peat-extracted zone of the Moss Spur peatland (Manitoba, Canada) and of each vegetation group (G1-G3) of the site. Various publications were used to associate a habitat to each plant species surveyed, notably Flora of North America (1993+), Crow and Hellquist (2000), Garneau (2001), Faubert (2013, 2014), and Lichvar et al. (2014).

\begin{tabular}{lllll}
\hline Species category & Entire site & $\begin{array}{l}\text { G1- } \\
\text { Scirpus }\end{array}$ & $\begin{array}{l}\text { G2- } \\
\text { Trichophorum }\end{array}$ & $\begin{array}{l}\text { G3- } \\
\text { Eriophorum }\end{array}$ \\
\hline Vascular plant species $(n)$ & 97 & 92 & 73 & 35 \\
Bryophyte species $(n)$ & 40 & 30 & 30 & 24 \\
Wetland species $(n)$ & 113 & 104 & 87 & 44 \\
Bog species $(n)$ & 24 & 22 & 22 & 15 \\
Fen species $(n)$ & 42 & 38 & 35 & 17 \\
Frequency of occurrence of wetland species $(\%)$ & 93 & 88 & 98 & 98 \\
Frequency of occurrence of bog species (\%) & 39 & 24 & 35 & 92 \\
Frequency of occurrence of fen species (\%) & 58 & 41 & 92 & 27 \\
Shannon's diversity index & 2.01 & 2.18 & 1.84 & 1.95 \\
\hline
\end{tabular}


Table 2. Mean frequency of occurrence of species having a frequency $\geq 5 \%$ in at least one vegetation group (G1-G3) of the peat-extracted zone of the Moss Spur peatland (Manitoba, Canada), and measured abiotic variables (mean value, standard deviation and minimummaximum values) within each group. See text for variable abbreviations.

\begin{tabular}{|c|c|c|c|}
\hline & G1-Scirpus & G2-Trichophorum & G3-Eriophorum \\
\hline \multicolumn{4}{|l|}{ Plant species } \\
\hline Aulacomnium palustris & 5 & 3 & 4 \\
\hline Betula papyrifera & 1 & 0 & 5 \\
\hline Betula pumila & 2 & 0 & 11 \\
\hline Calamagrostis canadensis & 5 & 1 & 2 \\
\hline Campylium stellatum & 6 & 5 & 0 \\
\hline Carex canescens & 14 & 6 & 12 \\
\hline Drosera rotundifolia & 3 & 18 & 8 \\
\hline Eriophorum vaginatum & 4 & 4 & 82 \\
\hline Larix laricina & 3 & 2 & 6 \\
\hline Liverworts spp. & 6 & 21 & 17 \\
\hline $\begin{array}{l}\text { Phragmites australis subsp. } \\
\text { americanus }\end{array}$ & 7 & 4 & 0 \\
\hline Polytrichum commune & 1 & 1 & 7 \\
\hline Polytrichum strictum & 1 & 3 & 16 \\
\hline Rhynchospora alba & 3 & 39 & 0 \\
\hline Salix bebbiana & 9 & 2 & 2 \\
\hline Scirpus cyperinus & 26 & 5 & 7 \\
\hline Trichophorum alpinum & 18 & 77 & 4 \\
\hline Typha spp. & 10 & 5 & 0 \\
\hline Vaccinium oxycoccos & 5 & 5 & 11 \\
\hline \multicolumn{4}{|l|}{ Abiotic variables } \\
\hline pH water & $5.7 \pm 0.6[4.3-6.9]$ & $5.4 \pm 0.6[4.3-6.2]$ & $4.6 \pm 0.7[4.3-5.0]$ \\
\hline pH peat & $5.6 \pm 0.5[4.3-6.4]$ & $5.3 \pm 0.6[4.2-6.7]$ & $4.6 \pm 0.6[3.8-5.3]$ \\
\hline Conductivity $\left(\mu \mathrm{S} \mathrm{cm}^{-1}\right)$ & $119 \pm 47[52-273]$ & $125 \pm 58[57-282]$ & $83 \pm 39[49-126]$ \\
\hline Water min $(\mathrm{cm})$ & $-12 \pm 5[-28-4]$ & $-9 \pm 5[-21--1]$ & $-11 \pm 7[-20--6]$ \\
\hline Water max $(\mathrm{cm})$ & $-7 \pm 2[-15-2]$ & $-5 \pm 2[-12-2]$ & $-8 \pm 2[-14--4]$ \\
\hline Water dif $(\mathrm{cm})$ & $5 \pm 1[1-13]$ & $3 \pm 2[1-9]$ & $4 \pm 3[2-6]$ \\
\hline Ca total $\left(\mathrm{mg} \mathrm{g}^{-1}\right)$ & $13.7 \pm 4.0[5.0-20.2]$ & $11.4 \pm 4.0[3.7-21.5]$ & $7.9 \pm 4.2[4.9-12.4]$ \\
\hline Pyrophosphate (index) & $5.8 \pm 0.9[3-7]$ & $5.7 \pm 1.1[3-7]$ & $5.6 \pm 0.9[3-7]$ \\
\hline Peat $(\mathrm{cm})$ & $170 \pm 34[83-278]$ & $218 \pm 43[109-300]$ & $170 \pm 49[126-229]$ \\
\hline
\end{tabular}




\section{Figure captions}

Fig. 1. Overview of the Moss Spur peatland (Manitoba, Canada) showing the 24 sectors (separated by the main drainage ditches) and the location of water table observation wells and sampling quadrats (summer 2014).

Fig. 2. Photographs of different Moss Spur peatland (Manitoba, Canada) sectors:

(a) sector A (G1-Scirpus), (b) sector C (G2-Trichophorum), (c) sector D (G2-Trichophorum), and (d) sector J (G3-Eriophorum). All photographs: F. Gagnon.

Fig. 3. Principal component analysis (PCA) illustrating plant species composition variation and similarities between quadrats sampled in the Moss Spur peatland (Manitoba, Canada), and the association between a selection of species and the quadrats. Quadrats are distinguished by group type (see text for the meaning of G1-G3). Species codes: betpum: Betula pumila, camste: Campylium stellatum, carcan: Carex canescens, drorot: Drosera rotundifolia, erivag: Eriophorum vaginatum, livspp: liverworts spp., phraus : Phragmites australis, polcom: Polytrichum commune, polstr: Polytrichum strictum, rhyalb:

Rhynchospora alba, salbeb: Salix bebbiana, scicyp: Scirpus cyperinus, trialp: Trichophorum alpinum, typspp: Typha spp., vacoxy : Vaccinium oxycoccos.

Fig. 4. Redundancy analysis (RDA) illustrating the influence of several variables on the plant species composition of quadrats sampled in the Moss Spur peatland (Manitoba, Canada). Quadrats are distinguished by group type (see text for the meaning of G1-G3). Variables (see text for the meaning of abbreviations) are represented by arrows (vectors). 
Fig. 5. Maps of the Moss Spur peatland (Manitoba, Canada) showing (a) the water table level in summer 2014 (a negative sign indicates a position below the soil surface), (b) difference in water table level between two datasets taken in summer 2014, (c) residual peat thickness, and (d) water $\mathrm{pH}$. The borders of the sectors of the peatland are indicated on the maps. The classes were separated by geometric intervals using ArcGIS software (ESRI 2015) to best represent spatial distribution patterns. See text for the meaning of quadrat groups (G1-G3). 


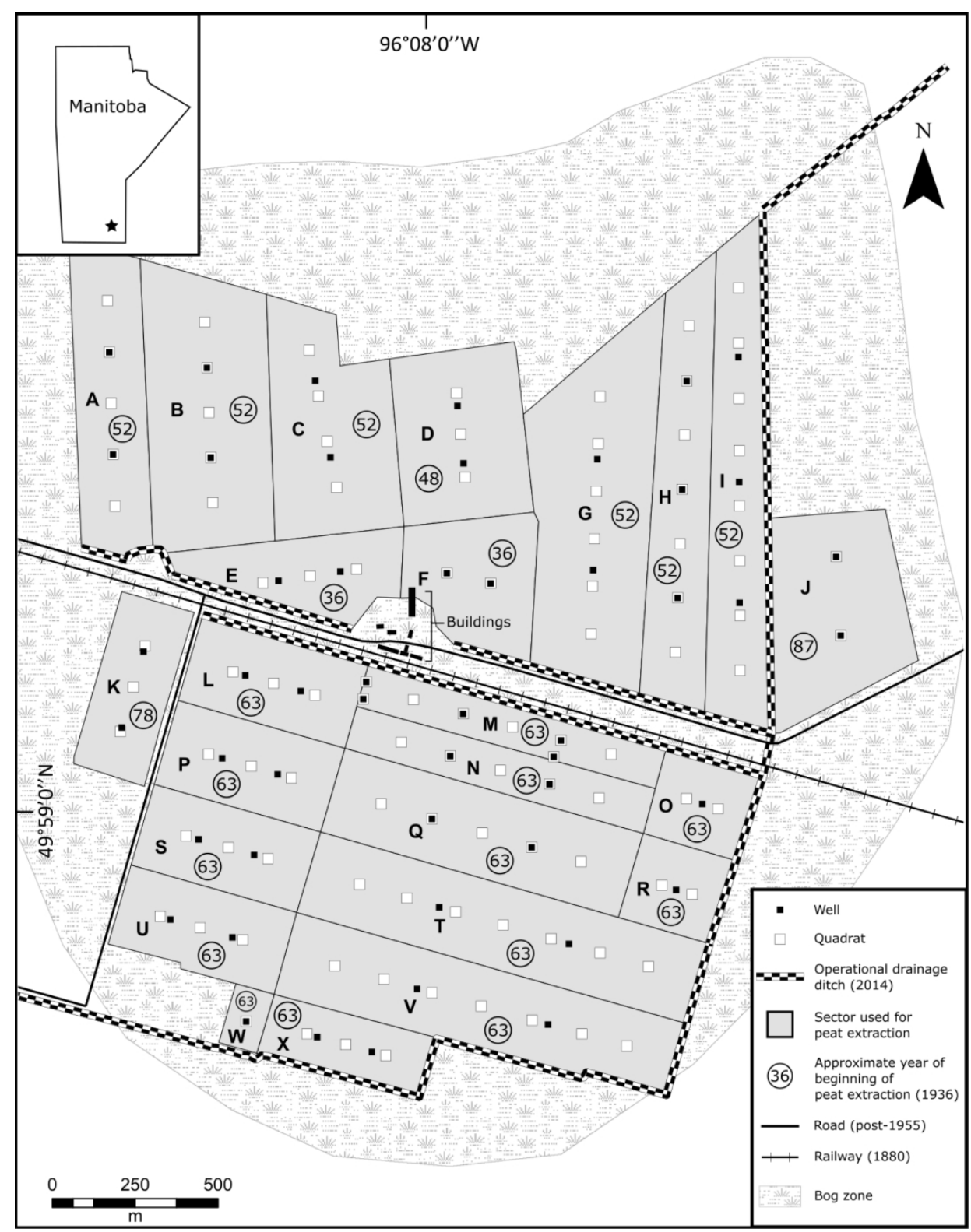

Fig. 1. Overview of the Moss Spur peatland (Manitoba, Canada) showing the 24 sectors (separated by the main drainage ditches) and the location of water table observation wells and sampling quadrats (summer 2014).

$212 \times 270 \mathrm{~mm}(300 \times 300$ DPI $)$ 


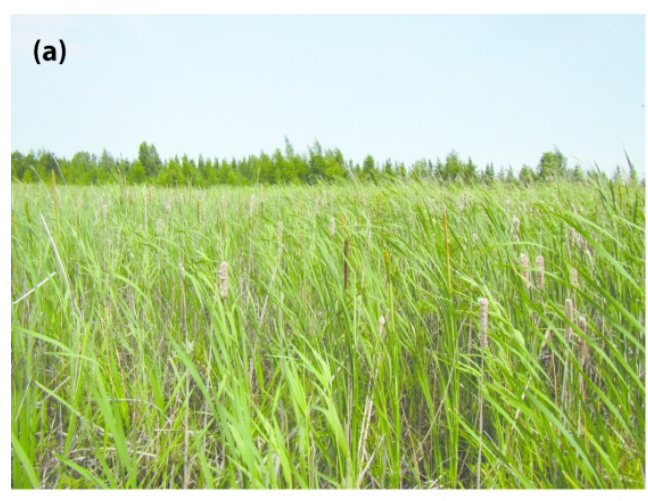

(b)
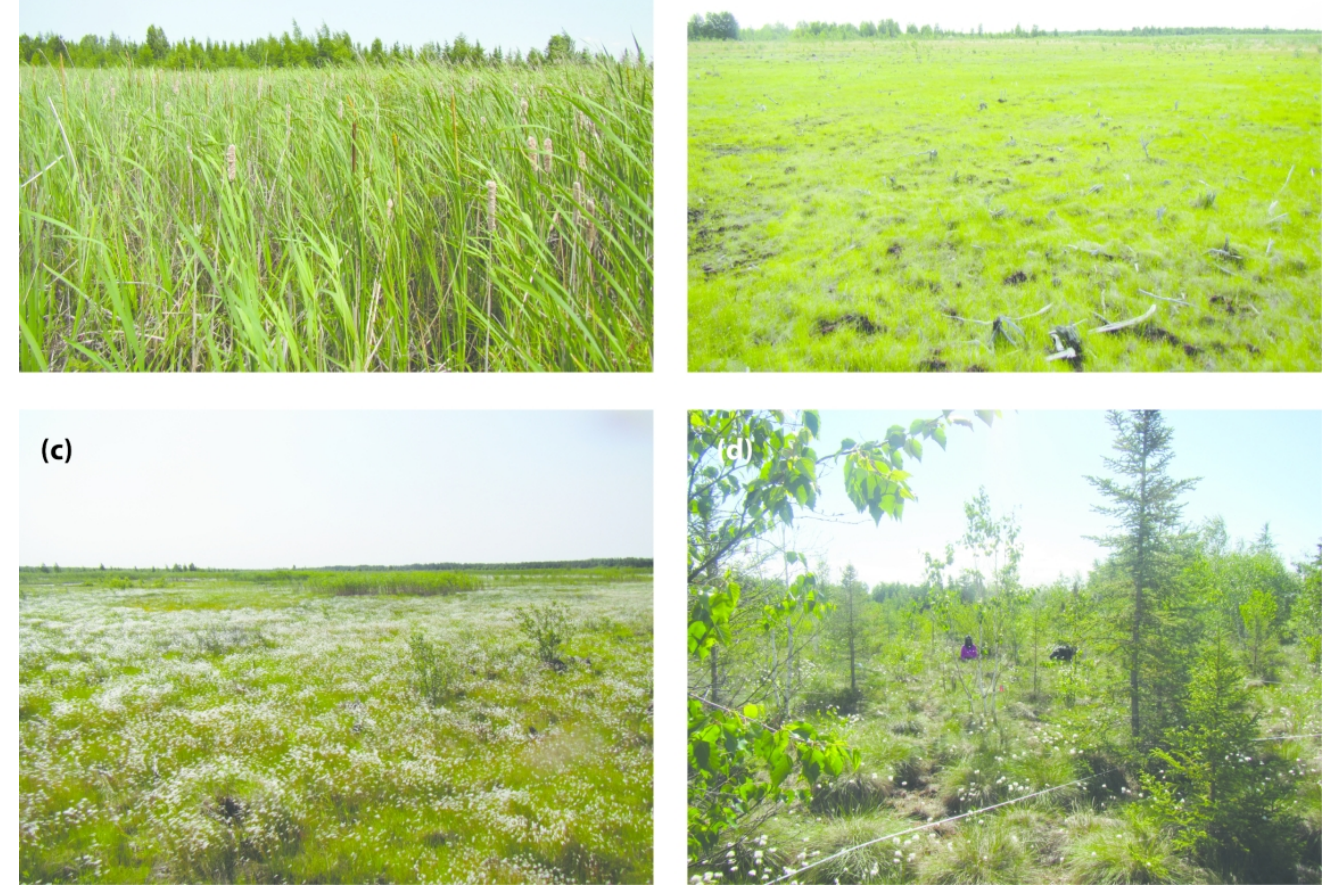

Fig. 2. Photographs of different Moss Spur peatland (Manitoba, Canada) sectors: (a) sector A (G1-Scirpus), (b) sector C (G2-Trichophorum), (c) sector D (G2-Trichophorum), and (d) sector J (G3-Eriophorum). All photographs: F. Gagnon.

$180 \times 137 \mathrm{~mm}(300 \times 300 \mathrm{DPI})$ 


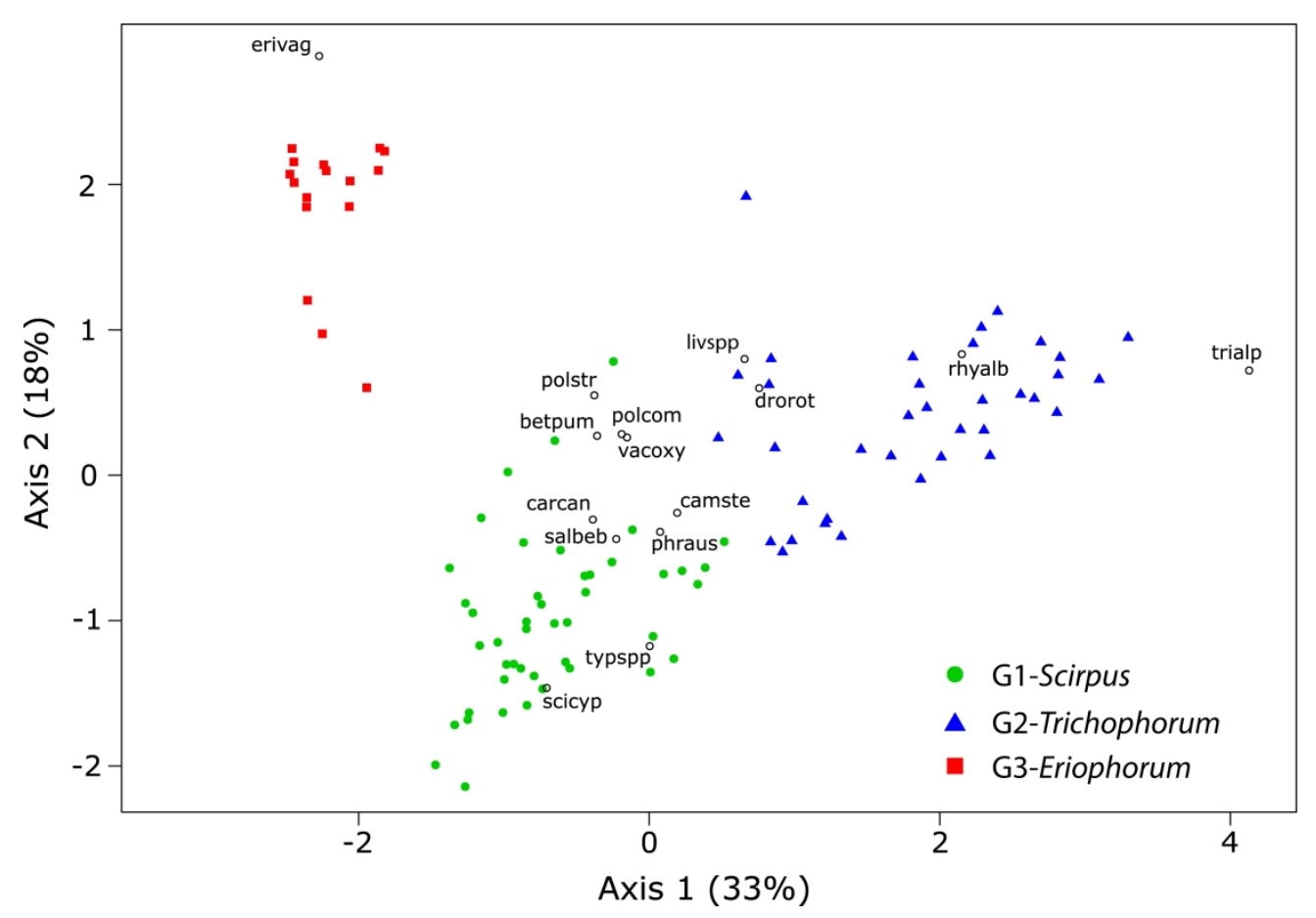

Principal component analysis (PCA) illustrating plant species composition variation and similarities between quadrats sampled in the Moss Spur peatland (Manitoba, Canada), and the association between a selection of species and the quadrats. Quadrats are distinguished by group type (see text for the meaning of G1-G3). Species codes: betpum: Betula pumila, camste: Campylium stellatum, carcan: Carex canescens, drorot: Drosera rotundifolia, erivag: Eriophorum vaginatum, livspp: liverworts spp., phraus : Phragmites australis, polcom: Polytrichum commune, polstr: Polytrichum strictum, rhyalb: Rhynchospora alba, salbeb: Salix bebbiana, scicyp: Scirpus cyperinus, trialp: Trichophorum alpinum, typspp: Typha spp., vacoxy : Vaccinium oxycoccos.

$252 \times 175 \mathrm{~mm}(300 \times 300 \mathrm{DPI})$ 


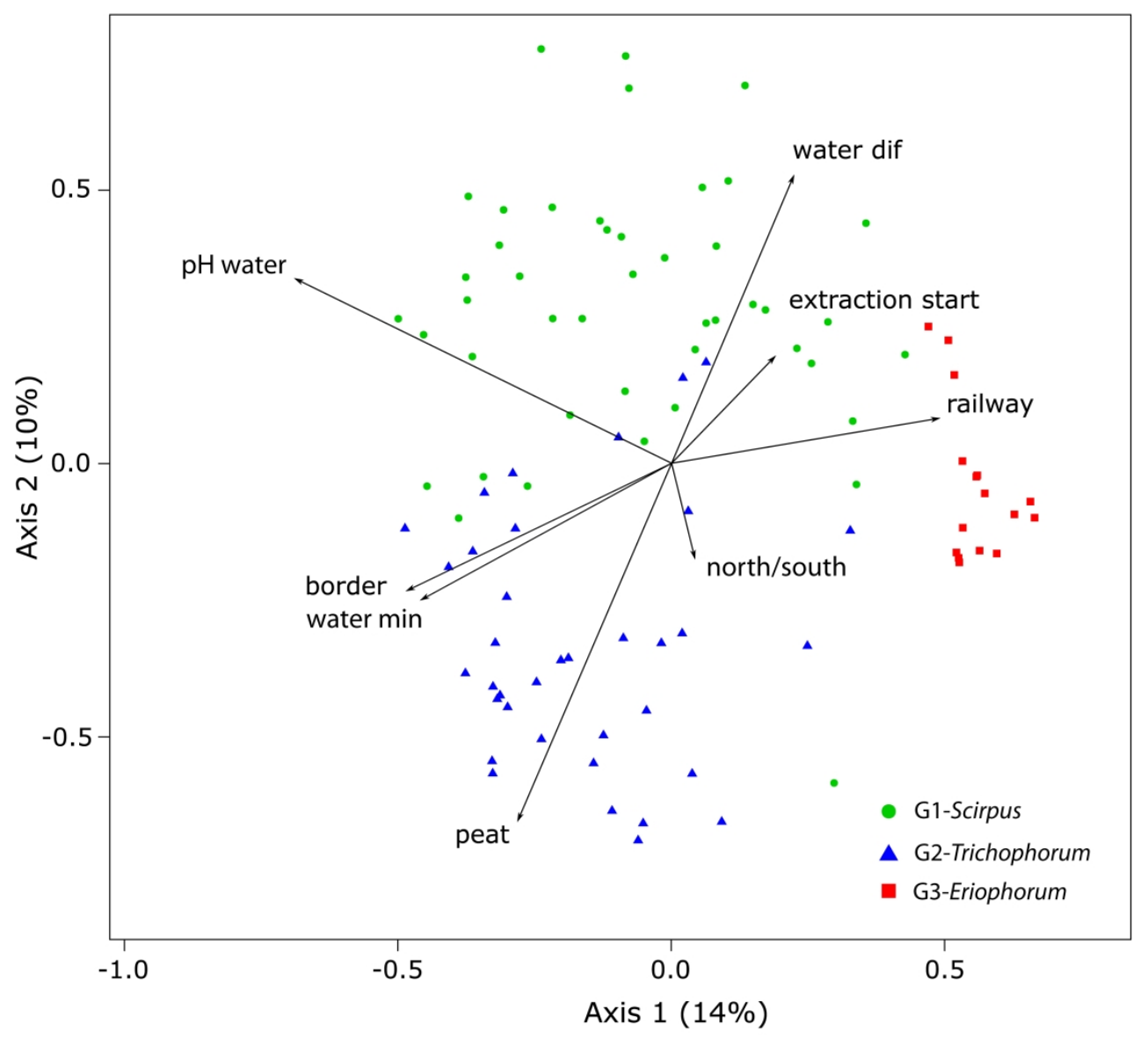

Redundancy analysis (RDA) illustrating the influence of several variables on the plant species composition of quadrats sampled in the Moss Spur peatland (Manitoba, Canada). Quadrats are distinguished by group type (see text for the meaning of G1-G3). Variables (see text for the meaning of abbreviations) are represented by arrows (vectors).

$261 \times 254 \mathrm{~mm}(300 \times 300 \mathrm{DPI})$ 


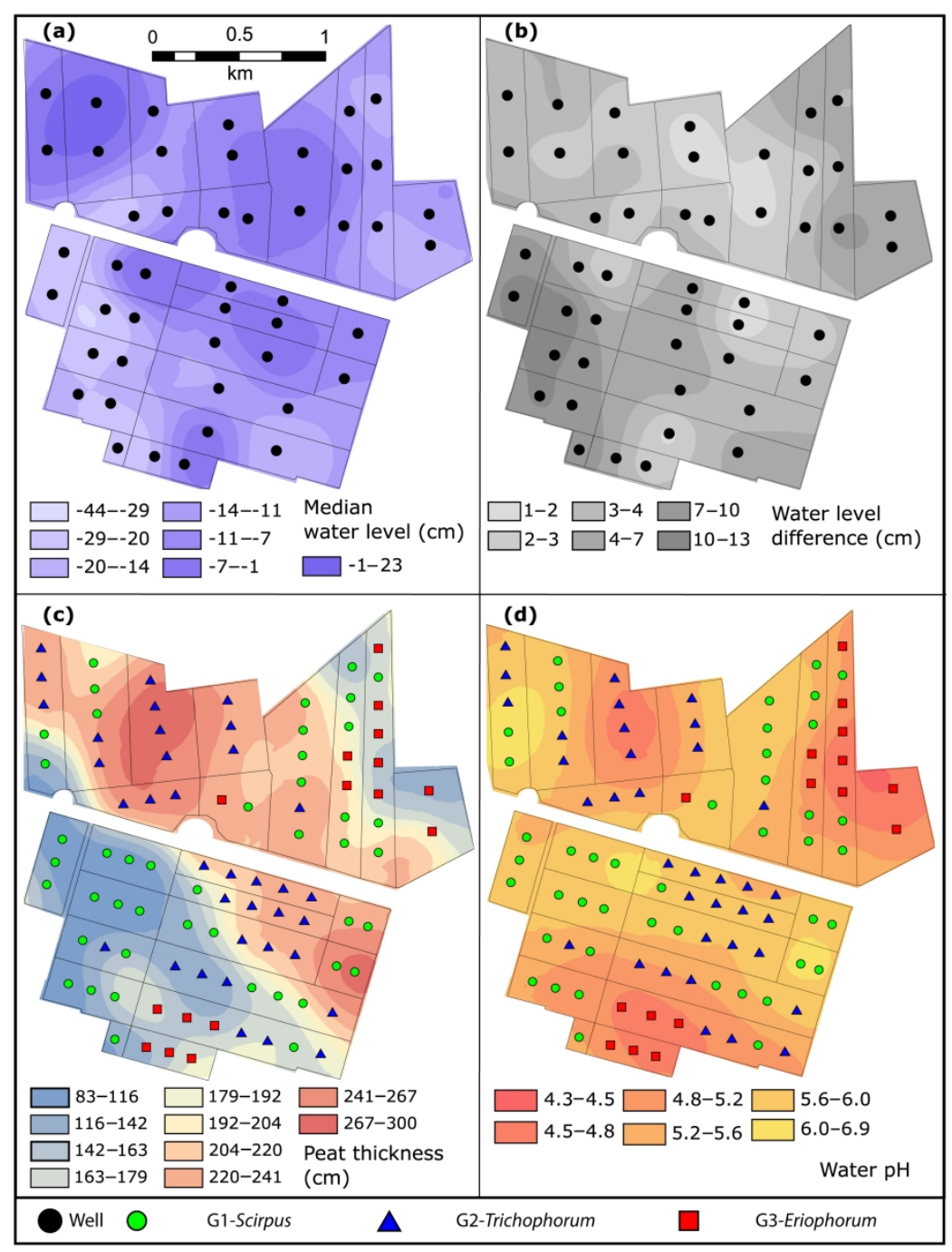

Fig. 5. Maps of the Moss Spur peatland (Manitoba, Canada) showing (a) the water table level in summer 2014 (a negative sign indicates a position below the soil surface), (b) difference in water table level between two datasets taken in summer 2014, (c) residual peat thickness, and (d) water pH. The borders of the sectors of the peatland are indicated on the maps. The classes were separated by geometric intervals using ArcGIS software (ESRI 2015) to best represent spatial distribution patterns. See text for the meaning of quadrat groups (G1-G3).

$256 \times 281 \mathrm{~mm}(300 \times 300 \mathrm{DPI})$ 